\title{
How To Invest Your IRA's In Profitable Real Estate IRA's
}

Raj Kiani, (E-mail: rkiani@csun.edu), California State University, Northridge M.A. Sangeladji, (E-mail: msangeldaji@csun.edu), California State University, Northridge

\begin{abstract}
Since the inception of Individual Retirement Accounts (IRAs) in 1974, the public has been advised strongly by bankers, accountants (CPAs), and investment advisors that the best strategy for IRA holdings is investment in stocks or bonds. Unfortunately, with the sharp decline in the market value of stocks and the bottoming out of interest rates in the past years, most IRA funds have performed very poorly and investors have witnessed how drastically their retirement savings lost their accumulated value. During these years, apparently, not many investment advisers have bothered to consider other alternative ways for investing accumulated IRAs and pension funds. There is, in fact, another viable investment alternative that offers both safety and a considerable growth rate. That is real estate IRAs. The purpose of this paper is to explain (a) why the traditional and Roth IRA should be invested in real estate, $b$ ) the steps involved in establishing a sound real estate IRA, (c) the restrictions and the dos and don'ts of investing in a real estate IRA, and (d) the tax and penalty consequences of incorrect investment in a real estate IRA.
\end{abstract}

\section{Buying Real Estate with your IRA}

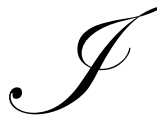

ndividual Retirement Account (IRA) was included in the Employee Retirement Income Security Act (ERISA) of 1974, which encouraged individuals to establish Tax-sheltered retirement accounts for themselves and/or their non-employed spouses. Self-investment and self-direction are the main intent and meaningful parts of the Act ${ }^{1}$. Even though the ERISA puts a maximum annual limit to the amount of contribution and investment in IRA, it does not limit the type of investment only in to mutual funds and/or stocks.

Generally speaking, one may not invest IRA's funds in a life insurance policy or collection items such as paintings, rugs, etc. However, one may invest the IRA fund in real estate such as single family and multi-unit homes, apartment buildings, co-ops, condominiums, commercial property, improved or unimproved land, whether it is leveraged or un-leveraged, real estate investment trusts, and limited partnerships (both private and/or public). For these types of investments, investors need to be more familiar with the Internal Revenue Rules and Regulations. In addition, investors must be willing to control and direct such investments to the level of risk and return that fits their comfort zone and the growth rate that will be self-sustaining during their retirement years.

\section{The following steps are recommended for a sound investment of IRA funds in real estate}

Setup a self-directed IRA

The first step for an investor is to open a self-directed IRA. Generally speaking, banks, insurance companies and brokerages can help an investor open a self-directed IRA. This self-directed traditional or ROTH IRA should be in the form of IRA trust. This trust may be in one of the following types: (a) an IRA custodian, (b) an independent IRA administrator, or (c) an IRA advisor. Each one the above IRA trustees is responsible to (a) review all of the appropriate documents concerning each investment opportunity, (b) compile the paperwork necessary for each transaction, (c) file the paperwork with the IRS, and (d) hold cash and title to properties, and all other assets of the IRA accounts. 
The major benefit of a self-directed IRA trust is that it allows the investor to take control of his own destiny and make his own investment decisions based upon the level of risk and return that fits his situation. Therefore, when an investor arranges his IRA with a self-directed administer, he will be in a position to take advantage of all the investment opportunities allowed by law, including those offered by his stockbroker, bank, or insurance company.

If possible, transfer your 401( $k$ ) or 403(b) funds to the self-directed IRA

Investment in real estate normally requires adequate funds. The amount accumulated in a regular or Roth IRA can be substantial if an account has been established for a long period of time. As one author put it "if a husband and wife each contribute only $\$ 3,000$ annually to an IRA from age 25 to age of 65 (and earn 6 percent annually), their amount balances together would be approximately $\$ 2.5$ million at the retirement." ${ }^{2}$

For some investors, however, the accumulated fund in their IRA accounts may not be adequate for investments in real estates. A rollover of 401(k) and/or 403(b) into an IRA is recommended in such cases. To accomplish this, the investor should set up an IRA with the administrator of his choice and sign a direct letter, instructing the administrator of the 401(k) and/or 403(b) to roll over the funds into a new self-directed IRA. Then, at an appropriate time, the accumulated and transferred funds can be invested into a desired real estate project.

The above suggestion is well suited for those high bracket professionals like physicians, attorneys, and executives who have accumulated a sizable amount in their retirement accounts. Another point that deserves some attention here is the issue of capital gains tax. This type of tax can be postponed if the capital gain is made by the real estate IRA trust instead of individual taxpayers.

Make sure to invest the maximum allowable amount annually in your IRA

The maximum contribution for an individual is the smaller of $\$ 3,000$ (or $\$ 6,000$ for husband and wife) for years 2002-2004 or 100 percent of the compensation. This maximum limit has been increased by $\$ 500$ for the period of 2002 through 2005 and by $\$ 1,000$ for years after 2005 for those taxpayers who reach the age of 50 by the end of the tax year. ${ }^{3}$.

\section{Educate yourself with Internal Revenue Codes (IRC) that governs IRAs}

Sections 408, 408A, and 4975 of IRS codes discuss the general rules and restrictions regarding to the Regular IRAs and, Roth IRAs transactions. ${ }^{4}$ The investors need to consult these sections for more directions.

\section{Escrow Account and Vesting Interest}

The process of purchasing real estate with IRA fund is very similar to purchasing other conventional investments, such as stocks, with a few exceptions. The entire transaction must flow through the tax-free or taxdeferred retirement account. The escrow must be opened by the trustee in the name of the self-directed IRA account, and not in the name of the beneficial owner. Vesting is always in the name of the account. Only a Qualified Plan or IRA funds may be used as good faith deposits, down payments, or purchase money. There are, however, some important transaction rules that should be kept in mind. For instance, when properties are purchased by a selfdirected IRA account, they become assets of the IRA account. The following are some of the restrictions related to the real estate IRA account: ${ }^{5}$

\section{Restrictions}

- $\quad$ You may not personally own property, which you intended to purchase with Plan funds and you must ensure that your intended purchase is not a prohibited transaction

- $\quad$ The property must be for investment purposes only

- $\quad$ Neither you, your spouse, nor your family members (other than siblings) may have owned the property 
prior to its purchase by your Plan

- $\quad$ Neither you nor your family members (other than siblings) may live in or lease the property while it is in your Plan.

- Your business (corporation, partnership, or LLC) may not lease or be located in or on any part of the property while it is in your Plan.

- $\quad$ Your IRAs or Qualified Plan are not permitted to be investors in Sub Chapter S corporations.

- $\quad$ All income generated from all rental profits and the sale of a property owned by your IRA must return directly to the IRA.

\section{Penalties for Violation from Rules and other Tax Considerations}

If IRS criteria for a self-directed IRA and qualified withdrawals are not followed, significant tax and penalties could be assessed by the IRS. The assessed combined penalties and income taxes can range anywhere from $15 \%$ to more than $100 \%$ of the IRA's value or the value of real estate. In addition, the owners of IRA account must be aware of the mandatory distribution rule enforced by the IRS once the owners reach the age of 70.5. At that time the property that was purchased by the IRA fund must have generated enough income to provide for the required distributions. Otherwise, the IRS assesses a hefty $50 \%$ penalty on the amount of the minimum distribution that the IRA holder should have been receiving. Minimum IRA distributions are based on the taxpayer's age and the total value of all the taxpayer's IRAs.

\section{Unrelated Business Income Tax (UBIT)}

In accordance with Sections 511(b) and 512(a) of the Internal Revenue Code, an UBIT can be triggered against the real estate IRA income if the investment property has a mortgage. In other words, the income from an income producing real estate IRA, such as rental property, may not be considered deferred income and taxed on the year it is made. The basis for taxable income is computed after deductions are made for all appropriate expenses, including property tax and mortgage interest. The first $\$ 1,000$ of leftover income is tax free, and the balanced is taxed in proportion of mortgage to the purchase price. The ensuing illustrations should clarify the concepts of UBIT.

\section{First illustration}

Let's assume that a rental house was purchased with a real estate IRA for $\$ 200,000$ with a down payment of $\$ 100,000$, and a real estate IRA loan of $\$ 100,000$. Further, assume that the house has an annual rented income of $\$ 15,000$ and annual expenses, including mortgage interest, of $\$ 12,000$. The net income for this investment house is $\$ 3,000$, ( $\$ 15000-\$ 12,000)$. Since the first $\$ 1,000$ of net income is exempt from UBIT, only the $\$ 2,000$ balance is used for the computation of the tax. The taxable amount of income in this example is $50 \%$ of $\$ 2,000$, or $\$ 1,000$, because the debt to investment ratio is $50 \%$. Assuming a trust tax rate of $36 \%$, the UBIT in this case is $\$ 360$.

It should be noted that when real estate IRA investments are purchased with mortgage loans, a portion of the capital gains tax, normally postponed, can be due in the year that investment is sold. The following illustration explains such cases.

\section{Second illustration}

Let's assume that (a) the subject property in previous illustration is sold for a net consideration of $\$$ 300,000 , (b) the adjusted basis for the property after $\$ 20,000$ accumulated depreciation is $\$ 180,000$, and (c) the outstanding balance of the loan is $\$ 75,000$. The gain in this transaction is $\$ 120,000$. Since the debt to consideration ratio in this example is $25 \%(75,000 / \$ 300,000)$, the UBIT will trigger a capital gain tax on $\$ 30,000$ of $\$ 120,000$ total gain. The not-postponed capital gain tax due is 15 percent of $\$ 30,000$ or $\$ 4,500$.

The tax burden of UBIT, however, disappears one year after the loan is paid off. As a result at the time of sale, all capital gains will go directly into the IRA tax deferred, if all the mortgages are paid one year before the property sales. 


\section{Educate yourself about Real Estate Investments}

Real estate investing through an IRA provides good investment opportunities for individuals who are knowledgeable about real estate investing or work with knowledgeable advisors and/or brokers. Investing in real estate for retirement could serve as a means to diversify a retirement portfolio and to hedge against the cyclical changes in the economy and stock market. It should be emphasized at this point that in making real estate investment decisions, most important factor for success is location. For a successful investment, make sure that you work closely with a trustworthy commercial real estate broker in your area and consult with your accountant and attorney.

It should be remembered that investment opportunities in real estate will occur occasionally and will not last forever. To take advantage of such investment opportunities, you should have a liquid self-directed IRA in a money market account.

\section{Summary and Conclusion}

With today's economic uncertainty and low interest rates, more people are turning to alternative investments such as real estate, which could provide more protection and better potential return than traditional stocks and mutual funds. By investing in IRA accumulated funds in real estate, one could gain potential appreciation, more income, and avoidance of capital gains tax on the sale of property. The suggested steps for this type of investment are: (a) creation of a self-directed IRA account, (b) transfer funds from 401(k) or 403(b) funds to the self-directed IRA, if possible, (c) deposit of the maximum annual allowable amount in the self-directed IRA account, (d) better understanding of the Internal Revenue Codes (IRC) that governs IRAs, and (e) consummation of all the purchase transaction through a self directed IRA account and the escrow account which is opened in the name of the self-directed IRA account and not in the name of the beneficial owner.

To invest successfully IRA funds in real estate without unfavorable tax and legal consequences, the property must be for investment purposes and not personal use. It should not belong to the owner of an IRA account before the purchase by the IRA plan. It cannot not be used or leased as a residence or for other purposes by you, your family members (other than siblings), or your business (corporation, partnership, or LLC) while it is in your Plan. And finally, your IRA Plan cannot be an investor in Sub Chapter S corporations, and all income generated from all rental profits and the sale of a property owned by your IRA must return directly to the IRA. Violations of the IRS codes and regulations could cause harsh penalties and taxes against the real estate IRA. The UBIT tax is another tax that could be triggered if investment property acquired by an IRA fund has mortgage and generates income in excess of $\$ 1,000$.

In short, if the process of investing IRA funds in real estate is done properly, it could become very successful project. It is, indeed, well suited for those high bracket professionals like physicians, attorneys, and executives who have accumulated a sizable amount in their retirement accounts.

\section{Endnotes}

1. Internal Revenue Code, Sections 408 \& 408 A

2. Hoffman/Smith/Willis, Individual Income Taxes, 2004 Edition, Thompson Publishing Company. P 19-20

3. I I bid, $\mathrm{p} 19-20$

4. IRS Codes, Sections (408, 408 A, and 4975). Furthermore, see IRS publication 590, Individual Retirements Arrangements (IRAs) which provides detailed information on IRAs, including guidelines for making withdrawals.

5. IRS Code, Section 4975 